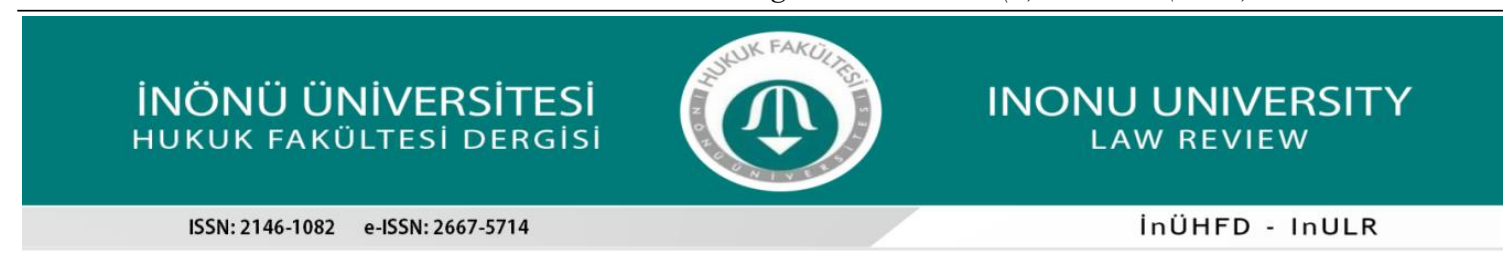

\title{
ALMAN CEZA HUKUKUNDA TAM SARHOŞLUK SUÇUNUN DOGMATIK TEMELLERİ
}

\author{
THE DOGMATIC FOUNDATIONS OF THE CRIME OF FULL DRUNKENNESS \\ IN GERMAN CRIMINAL LAW
}

\begin{abstract}
Uğur ERSOY* $\cdots$
Makale Bilgi

Gönderi: 11/07/2021

Kabul : 15/09/2021

\section{Anahtar Kelimeler}

Tam Sarhoșluk, Sarhoşluk, Kusur Prensibi, Tehlike Suçu.

Özet

https://dai.org/l0.21492/inuhfd.969786 do

Mevcut çalışmanın ana uğraş alanını, Alman Ceza Kanunu'nun 323a paragrafinda kaleme alınmış olan tam sarhoşluk (Vollrausch) suçunun dogmatik temelleri hakkında genel bilgiler verilmesi oluşturmaktadır. Söz konusu suç tipi ile toplumun genelinin, bir tehlikenin gerçekleşmesinden önce korunması amaçlanmıştır. Alman Ceza Kanunu'nda düzenlenmiş bulunan tam sarhoşluk suçuna benzer nitelikte bir suç tipine ne 765 sayıllı Türk Ceza Kanunu'nda ne de 5237 sayılı Türk Ceza Kanunu'nda yer verildiği görülmektedir. Tam sarhoşluk suçunun Alman ceza hukukunda önemli tartışmaların odağında yer aldığı söylenebilir. Gerçekten de Alman Hukukunda bu suç tipi, ceza hukuku dogmatiğinin en zorlu ve tartışmalı hükümlerinden birisi olarak değerlendirilmektedir. Söz konusu tartışmaların temelinde tam sarhoşluk suçunun ve bu suç tipinde aranan hukuka aykırı bir fiil (eine rechtswidrige Tat) gerçekleşmesinden ne anlaşılması gerektiği ve belki daha da önemlisi bu suç tipinin kusur prensibine aykırılık teşkil edip etmediği gibi önemli konular yatmaktadır. Çalışmanın sonuç kısmında ise Türk Ceza Kanunu'nda bu suç tipine benzer bir suça yer verilmesi gerekip gerekmediği hususu üzerinde kısa bir değerlendirmede bulunulacaktır.
\end{abstract}

\section{Article Info}

Received: 11/07/2021

Accepted: 15/09/2021

\section{Keywords}

Full Drunkenness, Drunkenness

Principle of Fault, Crime of Danger.

\section{Abstract}

The main field of the study is the dogmatic foundations of the crime of full drunkenness (Vollrausch) which is regulated in paragraph 323a of the German Criminal Code. With this type of crime, it is aimed to protect the general public before a danger occurs. This type of crime similar to this crime regulated in the German Criminal Code is neither included in the Turkish Criminal Code No. 765 nor 5237. It can be said that the crime of full drunkenness is at the center of important discussions in German criminal law. Indeed, in German Law, this type of crime is considered as one of the most challenging and controversial provisions of criminal law dogmatics. On the basis of these discussions, there are important issues such as the legal nature of the crime of drunkenness and the realization of an illegal act (eine rechtswidrige Tat) sought in this type of crime, and whether this type of crime constitutes a contradiction with the principle of fault. In the conclusion part of the study, brief explanations will be made on whether this type of crime should be included in the Turkish Criminal Code or not. 


\section{EXTENDED SUMMARY}

The crime of total drunkenness, which is regulated in the German Criminal Code, has no direct equivalent in either the Turkish Criminal Code 765 or the Turkish Criminal Code No. 5237. On the other hand, between articles 571 and 575 of the Turkish Criminal Code No. 765, it is seen that the act of drunkenness is regulated as a misdemeanor crime. It is noteworthy that the act of drunkenness is regulated as a misdemeanor in Article 35 of the Misdemeanor Law No. 5326. From this point of view, it can be said that there is no crime type that can be directly compared with the total drunkenness crime in the German Criminal Code and the Turkish Criminal Code No. 5237.

At this point, we find it useful to briefly mention the statements made by Jescheck in order to compare the situation in Turkish and German Laws. According to the author, the provisions of Turkish Law on drunkenness are stricter than the German Law. While all types of voluntary drunkenness are not considered in terms of criminal liability in Turkish Law, only ALIC (actio libera in causa) is regulated in this way in German Law. On the other hand, the state of drunkenness, which is caused intentionally or by negligence, is written in paragraph 323a of the German Criminal Code as a special type of crime. If the perpetrator commits a crime while intoxicated, drunkenness is considered a condition of objective punishment and the fault need not cover it. At this point, it is noteworthy that Jescheck's determination that German court-laws come to the limit of objective responsibility when determining punishment for crimes committed when the perpetrator is drunk through his own fault.

The reason why $\S 323 a$ is discussed so much in terms of German Law is the fact that the German Criminal Code does not include a regulation similar to the one in article 34 of the Turkish Criminal Code. In this context, an opinion in the German criminal law doctrine does not consider it possible to punish the perpetrator even in the presence of actio libera in causa, since there is no normative regulation; because the rule is very simple: If there is no fault, there is no punishment! (Keine Strafe ohne Schuld!). According to those of this opinion, in such a case, the criminal liability of the perpetrator can only be in question within the framework of $\S 323 a$. In contrast, the prevailing view in German doctrine is that $\S 323 a$ is a norm that can come into play where ALIC is not feasible; in other words, $\S 323 a$ will not be applicable if actio libera in causa has the possibility to apply.

In our opinion, the view put forward in German doctrine to harmonize the type of crime in question with the principle of fault, which is another of the issues discussed during the study, which seeks that the act committed by the perpetrator while intoxicated should at least be "predictable" in order to punish the perpetrator. Because the concept of "predictability" is a term related to negligence. In caste, what is foreseen must also be either "desired" (dolus directus) or at least "accepted" (dolus eventualis). In a type of crime that the legislator has not regulated in the form of negligence, seeking the existence of "predictability" in order to punish the perpetrator is an objectionable situation that may result in a substitute for the legislator, even if it aims to harmonize the type of crime with the principle of fault.

Is it necessary to regulate a type of crime similar to the crime of total drunkenness in the Turkish Criminal Code? In our opinion, in view of the fact that the regulation in Article 34 of the Turkish Criminal Code, and therefore the ALIC principle, is still in force in terms of our law, although it is controversial, there is no need to include a provision similar to the one in the Turkish Criminal Code $\S 323 a$. Moreover, as it is tried to be explained within the scope of the study, considering the serious and justifiable criticisms in the German criminal law doctrine that the said type of crime is against the principle of fault, it is also clear that the inclusion of such a problematic type of crime in the Turkish Criminal Code in terms of criminal law dogmatics and incompatible with the fault principle would do more harm than good. We think that the regulation will create inconsistency with Article 34 of the Turkish Criminal Code. 


\section{GÍRIŞ}

Alman Ceza Kanunu'nun (Al.CK) 323a paragrafında "tam sarhoşluk" (Vollrausch) suçuna yer verilmiştir. Alman Hukukunda bu suç tipi, ceza hukuku dogmatiğinin en zorlu ve tartışmalı hükümlerinden birisi olarak değerlendirilmektedir ${ }^{1}$.

Al.CK § 323a şu şekildedir:

"(1) Her kim, kasten veya taksirle, alkollü içecekler veya diğer sarhoş edici maddeler kullanarak kendini sarhoş eder ve bu durumda iken hukuka aykırı bir fiil gerçekleştirir ve sarhoşluğu nedeniyle kusur yeteneği bulunmadı̆̆ veya kusur yeteneği bulunduğu belli olmadı̆̆ için cezalandırllmazsa, beş yıla kadar hapis cezası veya adli para cezası ile cezalandırılır.

(2) Verilecek ceza, sarhoşken işlenen fiil için öngörülen cezadan daha ağır olamaz.

(3) Sarhoşken işlenen fiil, sadece şikâyet, izin veya talep üzerine soruşturulabilen bir fiil ise, fiil sadece şikâyet, izin veya talep üzerine soruşturulur."

Söz konusu suç tipi ile toplumun genelinin, bir tehlikenin gerçekleşmesinden önce korunması amaçlanmıştır. Zira tam sarhoş haldeki birisinin norma uygun davranma yeteneği genel yaşam tecrübelerine göre çoğunlukla ortadan kalkmış olmaktadır ${ }^{2}$. Bundan dolayıdır ki failin cezalandırılmasının nedeni, kendi iradi fiiliyle kusur yeteneğini ortadan kaldırmış olması ve böylelikle de toplum için genel tehlikeli bir durum içinde bulunuyor olmasıdır ${ }^{3}$. Buradaki problemin temeli, kusur prensibini kabul etmiş olan bir ceza hukuku sisteminde, bireysel özgürlüklerin hangi dereceye kadar sinırlandırılacağı noktasındaki zorlukta toplanmaktadır ${ }^{4}$.

\section{TAM SARHOŞLUK SUÇUNUN HUKUKİ NITELIĞİ VE KUSUR PRENSİBi KARŞISINDAKİ KONUMU}

Alman doktrinindeki hâkim görüş tam sarhoşluk suçunu soyut tehlike suçu olarak kabul etmekte ve bu durumdaki bir failin cezalandırılabilmesini kusur prensibine aykırı görmemektedir ${ }^{5}$. Hâkim görüş tarafından söz konusu suç tipi ile yasaklanan davranışın yalnızca iradi sarhoşluk olduğu ifade edilmektedir.

Bununla birlikte Alman Federal Yüksek Mahkemesi söz konusu suç tipini “soyut tehlike suçunun kendine özgü bir türü” olarak değerlendirmekte ve sarhoşluk içerisindeyken işlenen fiili,

\footnotetext{
${ }^{1}$ BEMMANN, Günter: "Welche Bedeutung hat das Erfordernis der Rauschtat im § 330a StGB?", GA 1961, s.65. Benzer görüşte bkz. KAUFMANN, Arthur: "Unrecht und Schuld beim Delikt der Volltrunkenheit”, JZ 1963, s.425. Söz konusu hükmü kanun koyucunun bir hatası olarak gören görüş için bkz. OTTO, Harro: "Der Vollrauschtatbestan (§ 323a StGB)", JURA 1986, s.478 ve dn.3'teki yazarlar.

${ }^{2}$ Gerçekten de Almanya'da işlenen bütün suçların yaklaşık yüzde onunun alkol etkisi altında işlendiği ifade edilmektedir. Bkz. KERNER, Hans-Jürgen: Kriminologie Lexikon, 4. Auflage, Heidelberg 1994, s.107.

${ }^{3}$ Doktrinde Hardwig, tam sarhoşluğun tehlikeli bir durum olduğunu ancak bunun, sarhoş olmanın yasaklanması için başlı başına yeterli bir neden olmadığını ifade etmektedir. Yazar, böyle bir durumu sosyal açıdan uygun (Sozialadäquanz) olarak görmekte ve hukuk düzeninin de buna katlanmak zorunda olduğunu ifade etmektedir. Bkz. HARDWİG, Werner: "Studien zum Vollrauschtatbestand" in: Festschrift für Eberhard Schmidt zum 70. Geburtstag, 1971, s.460.

${ }^{4}$ GEISLER, Claudius: Zur Vereinbarkeit objektiver Bedingungen der Strafbarkeit mit dem Schuldprinzip - Zugleich ein Beitrag zum Freiheitsbegriff des modernen Schuldstrafrechts, Berlin 1998, s.363.

${ }^{5}$ Bu görüşteki yazarlar için bkz. WESSELS, Johannes/HETTINGER, Michael: Strafrecht Besonderer Teil 1 - Straftaten gegen Persönlichkeits- und Gemeinschaftswerte, 35. Auflage, Heidelberg 2011, §23 Rn.1028; HOHMANN, Olaf/SANDER, Günther M.: Strafrecht Besonderer Teil II - Delikte gegen die Person und die Allgemeinheit, 2. Auflage, München 2011, $\$ 38$ Rn.2; SCHMIDT, Rolf/PRIEBE, Klaus: Strafrecht - Besonderer Teil I, Straftaten gegen die Person und die Allgemeinheit, 10. Auflage, 2011, §323a Rn.697; KINDHÄUSER, Urs: Strafrecht Besonderer Teil I - Straftaten gegen Persönlichkeitsrechte, Staat und Gesellschaft, 5. Auflage, Baden-Baden 2012, §71 Rn.3; GÖSSEL, Karl Heinz/DÖLLING, Dieter: Strafrecht Besonderer Teil 1 - Straftaten gegen Persönlichkeits- und Gemeinschaftswerte, 2. Auflage, Heidelberg 2004, §59 Rn.1; EISELE, Jörg: Strafrecht - Besonderer Teil I, Straftaten gegen die Person und die Allgemeinheit, 2.Auflage, Stuttgart 2012, §323a Rn.1223; DENCKER, Friedrich, "Vollrausch und der sichere Bereich des §21 StGB", NJW 1980, s.2160. Geisler, Alman doktrininde ve yargı kararlarında ağırlıklı olarak savunulan görüşe göre tam sarhoş halde iken işlenen fiilin sadece objektif cezalandırılabilme şartı olarak yorumlandığını ancak doktrindeki bu görüş sahiplerinin de kendi içlerinde iki farklı temel konsepti savunduklarını ifade etmektedir: İlk görüştekilere göre kusur prensibi ile tam sarhoş halde iken işlenen fiilin objektifliğinin, haksızlık alanında çözülmesi gerekmektedir. Tam sarhoşluk suçunun haksızlığı, tipik haksızlığın dışında bulunan objektif cezalandırılabilme şartı olarak tanımlanmaktadır. $\mathrm{Bu}$ görüştekilerin amacının, kusur prensibi ile olan uyuşmazlıklardan kaçınma yolunda olduğu görülmektedir. Çünkü şayet söz konusu bir şart haksızlık açısından önem arz eden bir duruma işaret ediyorsa bu durumda kusur prensibine aykırılık olması da kaçınılmazdır. Buna karşın, şayet objektif cezalandırılabilme şartı fiilin haksızlığı açısından önemsiz ise, o takdirde kusur prensibine aykırılıktan söz etmek mümkün olmayacaktır. İkinci görüştekilerin yaklaşımı ise söz konusu durumu kusur alanında değerlendirme yönündedir. Hâkim görüşü de teşkil eden ilk görüştekilerden farklı olarak bu görüş sahipleri, tam sarhoş halde iken bir suç işlenmesini haksızlık açısından kurucu bir önemde görmektedirler. Buna göre söz konusu şartların kusur prensibiyle bağdaştırılabilmesi, tipik haksızlık alanının geniş bir şekilde yorumlanması yoluyla değil, bilakis kusur prensibinin sınırlandırıcı anlayışı yoluyla mümkün olabilir. Bkz. GEISLER, Objektive Bedingungen der Strafbarkeit, s.366-367.
} 
sarhoş olan kişinin toplum açısından yarattığı tehlikelilik için zorunlu bir ispat vasıtası olarak görmektedir ${ }^{6}$. Ayrıca öğretide bir yandan Alman Ceza Kanunu'nun sistematiği, diğer yandan kanun koyucunun amacı dikkate alındığında, tam sarhoşluk suçunun kendine özgü bir suç olduğu da savunulmaktadir? .

Buna karşılık Alman doktrininde azınlıkta kalan görüş sahipleri, sarhoşken işlenen fiilden dolayı failin kusurlu addedilip cezalandırılabilmesinin söz konusu olabilmesi için bu suçun somut tehlike suçu veya daha başka bir ifadeyle somut tehlike suçunun özel bir türü olarak kabul edilmesi gerektiğini ifade etmektedirler. Bu görüssteki yazarlar, failin kastının veya taksirinin sarhoş olmadan önce bu fiille ilişkili olmaması gerektiğini de ifade etmektedirler ${ }^{8}$. Alman doktrininde azınlıkta kalan bu görüş sahipleri, sarhoşken işlenen hukuka aykırı bir fiilin yani haksızlığın, Al.CK § 323a'nın haksızlık ve kusur ilişkisi bağlamında ele alınması gerektiğini savunmaktadırlar. Bu görüştekilerin ağırlıklı dayanak noktasını, mevcut hükmü somut tehlike suçu olarak kabul etmeleri oluşturmaktadır. Bu yazarlara göre sarhoşken işlenen fiilde ex ante bir bakış açısıyla öngörülebilir tehlikeyi kurucu durumlar gerçekleşmek zorundadır; böylelikle haksızlık ve kusur arasında bulunması gereken zorunlu ilişki, sarhoş olma ve sarhoşken işlenen fiil arasındaki ilişkiyi de kurmuş olacaktır?.

Alman doktrininde hâkim görüşü oluşturan ve tam sarhoşluk suçunun kusur prensibine aykırılık oluşturmadığını savunanlara göre kusur prensibi ile objektif cezalandırılabilme şartı arasındaki çatışma durumu haksızlık aşamasında çözüme kavuşturulabilir. Şöyle ki; objektif cezalandırılabilme şartlarının tipik haksızlığın dışında bulunması sebebiyle kusur prensibine bir aykırılık oluşmamaktadır. Başka bir ifadeyle, sarhoş durumda iken işlenen hukuka aykırı bir fiil, haksızlık açısından önem arz etmeyen (unrechtsneutrale) objektif cezalandırılabilme şartını oluşturmaktadır; zira burada cezaya layık davranış kişinin kendi kendini sarhoş hale getirmesidir. Buna karşlık, kendi kendini sarhoş hale getirmenin haksızlık içeriğini aşırı derecede alkol tüketilmesi değil, bilakis sarhoş durumda bulunarak toplum için tehlikelilik yaratılması oluşturmaktadır ${ }^{10}$.

Bununla birlikte söz konusu suç tipinin kusur prensibine aykırılık oluşturduğu hususunda da çeşitli görüşler mevcuttur ${ }^{11}$. Alman doktrininde tam sarhoşluk suçunun mevcut haliyle kusur prensibine aykırılık oluşturduğu hususunda en net görüşte olan yazarların başında Geisler gelmektedir ${ }^{12}$. Geisler'e göre burada kusur prensibine aykırılık teşkil eden bir objektif cezalandırılabilme şartı söz konusudur. Bu hükmün kusur prensibiyle uygun hale getirilebilmesi, başka bir ifadeyle kusur prensibiyle uzlaştırılabilmesi, kusur prensibine uygun bir yorum yapılması suretiyle mümkün olabilecektir ${ }^{13}$. Zira yazara göre sosyal açıdan uygun bir davranış olarak tek başına sarhoşluk, cezalandırılabilme için yeterli bir bağlantı noktası arz etmemekte ve bundan dolayı da hâkim doktrin tarafından iddia edildiğinin aksine failin sarhoş iken hukuka aykırı bir fiil gerçekleştirmesi cezayı kurucu (strafbegründend) bir etki doğurmaktadır ${ }^{14}$. Geisler'e göre şayet sarhoşken gerçekleştirilen fiil temel olarak fiilin haksızlığı açısından hiçbir öneme sahip değilse, neden sarhoşken işlenen fiil için verilecek cezanın, kişinin sarhoşken işlemiş olduğu fiil için öngörülen cezadan daha ağır olamayacağı ifade edilmiştir? Gerçekten de Al.CK'nın 323a paragrafının 2. fikrasında, bu madde uyarınca verilecek cezanın, kişinin sarhoş halde iken işlemiş

\footnotetext{
${ }^{6}$ BGHSt 16, 124, 125.

${ }^{7}$ GEISLER, Objektive Bedingungen der Strafbarkeit, s.377.

${ }^{8}$ Bu görüşteki yazarlar için bkz. OTTO, Vollrauschtatbestand, s.478 dn.9-10.

${ }^{9}$ LANGE, Richard: "Die Behandlung der Volltrunkenheit in der Strafrechtsreform", JR 1957, s.244 vd.

${ }^{10}$ WESSELS/HETTINGER, BT 1, §23 Rn.1028; HOHMANN/SANDER, BT II, §38 Rn.2; SCHMIDT/PRIEBE, BT I, §323a Rn.697; KINDHÄUSER, BT I, §71 Rn.3; GÖSSEL/DÖLLING, BT 1, §59 Rn.1; EISELE, BT I, §323a Rn.1223; DENCKER, NJW 1980, s.2160.

${ }^{11} \mathrm{Bu}$ görüş sahipleri için bkz. SONNEN, Bernd-Rüdeger: Strafrecht Besonderer Teil, Heidelberg 2005, s.252-253; WEBER, Hellmuth von: "Die strafrechtliche Verantwortlichkeit für die Rauschtat", Studien zur Strafrechtswissenschaft - Festschrift für Ulrich Stock zum 70. Geburtstag am 8. Mai 1966, Würzburg 1966, s.71.

${ }^{12}$ GEISLER, Claudius: “Objektive Strafbarkeitsbedingungen und 'Abzugsthese' - Methodologische Vorüberlegungen zur Vereinbarkeit objektiver Strafbarkeitsbedingungen mit dem Schuldprinzip”, GA 2000, s.174-176, 179.

${ }^{13}$ GEISLER, GA 2000, s.179.

${ }^{14} \mathrm{Bu}$ nedenle Geisler Al.CK'nın 323a paragrafının, Al.CK'nın kusur yeteneğini düzenleyen 20 ve 21. paragraflarına istisna teşkil ettiğini ifade etmektedir. Bkz. GEISLER, Objektive Bedingungen der Strafbarkeit, s.366-367. Geisler'e göre kişinin kendi kendine sarhoş olması cezaya muhtaç bir davranıştır (strafbedürftiges Verhalten), bu halde iken bir suç işlemesi ise objektif cezalandırılabilme şartıdır. Bu nedenle bu durum yazarın oluşturduğu “çıkarma tezi” nin (Abzugsthese) temel düşüncelerine aykırılık teşkil edecek ve doğal olarak kusur prensibine de aykırılık oluşturacaktır. Bkz. GEISLER, Objektive Bedingungen der Strafbarkeit, s.374-375. 
olduğu fiil için öngörülen cezadan daha ağır olamayacağının belirtilmiş olmas1 ${ }^{15}{ }^{16}$ ve yarg1 kararlarında da sarhoşken işlenen fiilin ağırlığının cezanın belirlenmesinde dikkate alınması bu tespitin haklılı̆̆ını ortaya koymaktadır ${ }^{17}$. Ayrıca Geisler, şayet hâkim doktrin tarafından savunulan görüş doğru ise neden Düzene Aykırılıklar Kanunu'nun (Gesetz über Ordnungswidrigkeiten) 122. Paragrafinda iradi sarhoşluğun sadece idari para cezasını gerektiren bir kabahat olarak kabul edildiğinin de tutarlı bir açıklamasının olamayacağını ifade etmektedir ${ }^{18}$.

Bu suç tipinin mevcut şekliyle kusur prensibine aykırılık oluşturduğunu savunan yazarlardan bir diğeri olan Roxin'e göre söz konusu suç tipinin kusur prensibine aykırılığı noktasında yapılan eleştirileri gidermek için, bu suçun sinırlayıcı bir şekilde yorumlanması gerekmektedir. $\mathrm{Bu}$ bağlamda kişinin cezalandırılabilmesi için, sarhoşluk ve sarhoşken işlenen fiil arasında bir taksir ilişkisi kurulması gerekmektedir. Başka bir deyişle failin sarhoşken işlemiş olduğu fiilin öngörülebilir olması zorunludur ${ }^{19}$. Roxin'e göre söz konusu suç için beş yıla kadar hapis cezası öngörülmesi ve ayrıca doktrinde ileri sürülen, cezalandırılabilirliğin sadece sarhoşluk halinde işlenen fiillerle sınırlandırılacağı ve böylelikle failin problemsiz bir şekilde cezadan kurtulacağ şeklindeki görüş tutarlı değildir. Bu nedenle hüküm bu şekilde yorumlanırsa kusur prensibine aykırılık teşkil edeceği açıç̧a ortadadır. Roxin, bu durumun önüne geçilebilmesi için, failin, gerçekleşen fiilin sonuçlarını öngörebilmesi halinde cezalandırılabileceğini kabul etmektedir ${ }^{20}$. Bu şekilde yapılacak bir yorum, hem kusur prensibini ihlal etmiş olmaz hem de Anayasa'ya uygun olmuş olur ${ }^{21}$.

Frister de iradi sarhoşluğun beş y1la kadar hapis cezası gerektiren bir suç olarak kabul edilmesini, Alman toplumunda alkol kullanılmasının toplumun geneli açısından uygun görülen bir durum olması ve alkol kullanımının Alman toplumunda yaygın olması dikkate alındığında mantıksız ve anlamsız bulmaktadır. Ayrıca Frister, hâkim doktrin tarafından savunulduğunun aksine sarhoş olmanın tek başına cezaya layık bir fiil olarak kabul edilemeyeceğini de sözlerine eklemektedir. Bütün bu sebeplerden ötürü yazar, Al.CK § 323a'da aranan objektif cezalandırılabilme şartının kusur prensibine net bir şekilde aykırı olduğunu savunmaktadır. Yazar, öğretide giderek taraftar toplayan ve tam sarhoşluk suçunda aranan objektif cezalandırılabilme şartının, anayasaya uygun yorumlanması ve değerlendirilmesi sonucunda, bu suç dolayısıyla cezalandırmanın söz konusu olabilmesi için failin taksirinin varlığının aranması gerektiğini belirtmektedir. Başka bir deyişle failin, sarhoş olduğunda herhangi bir suç işleyebileceğini en azından öngörebilmesi durumunda cezalandırılması söz konusu olacaktır. Ancak Frister, maddenin bu şekilde yorumlanmasının, söz konusu hükmün açıklığı karşısında kesin olmayan ve palyatif bir çözüm olduğunu da ifade etmektedir ${ }^{22}$.

Geisler, tam sarhoşluk suçunun anayasaya uygun bir şekilde yorumlanabilmesi için bu suç tipinin somut tehlike suçu olarak değerlendirilmesi gerektiği yolundaki görüşe katılmaktadır. Buna göre failin kendi kendini sarhoş ettiği zamana gidilip, o zamanda failin daha sonra bir suç işleyebileceğini öngörebilip öngöremediğini araştırmak gerekmektedir. Ancak burada ikili bir ayrım yapılma zorunluluğu bulunmaktadır: İlk seçeneğe göre failin daha sonradan herhangi bir suç işleyebileceğini öngörebilmiş olması yeterliyken, ikinci seçeneğe göre failin herhangi bir suç işleyebileceğini öngörmüş olması yeterli olmayıp, işlemiş olduğu somut suçu işleyebileceğini öngörmüş olması gerekmektedir. Geisler, sarhoşluk ve sarhoşken işlenen fiil arasında sıkı bir kusur ilişkisinin varlığını öngören ikinci seçeneğin alkışı hak ettiğini belirtmektedir. Bu nedenle de

\footnotetext{
${ }^{15}$ GEISLER, GA 2000, s.175.

${ }^{16}$ Geisler ile benzer görüşlere sahip olan Ranft'a göre doktrinde savunulan, hukuka aykırı fiilin gerçekleştirilmiş olmasının cezayı gerekçelendirici değil, bilakis cezayı sınırlandırıcı bir fonksiyon ifa ettiği şeklindeki görüş doğru değildir. Zira bu görüşü savunanların ifade ettiği gibi gerçekten de ortada cezayı sınırlandırıcı bir fonksiyon söz konusuysa, haksızlık ve kusurun dışında bulunan objektif cezalandırılabilme şartı olarak sarhoşken işlenen fiilin anlamı, cezalandırılabilirliğin tamamen rastlantısal durumların varlığına bağlanması sonucunu doğurmaktadır. Ayrıca, örneğin Al.CK’nın 323a paragrafının 2. fikrasına göre cezanın sınırlandırılması ve 3. fikraya göre şikayetin belli durumlarda zorunlu olması hiçbir şekilde açıklanamaz. Yazara göre şayet failin kusuru ve fiilin haksızlı̆̆ önemsiz ise neden verilecek cezanın türü ve miktarı, failin sarhoş iken işlediği fiil için öngörülen cezadan daha ağır olamamaktadır? Neden ceza takibatının şartları, sarhoşken işlenen fiil için öngörülen şartlara tabi tutulmaktadır? Ayrıntılı bilgi için bkz. RANFT, Otfried: “Grundprobleme des Vollrauschtatbestandes (§ 323a StGB)”, JA 1983, s.194.

${ }^{17}$ GEISLER, Objektive Bedingungen der Strafbarkeit, s.368 vd.

${ }^{18}$ GEISLER, Objektive Bedingungen der Strafbarkeit, s.369.

${ }^{19}$ ROXIN, Claus: Strafrecht Allgemeiner Teil, Band I, Grundlagen - Der Aufbau der Verbrechenslehre, 4. Auflage, München 2006, §23 Rn.9.

${ }^{20}$ ROXIN, AT I, §23 Rn.8-11.

${ }^{21}$ GEISLER, Objektive Bedingungen der Strafbarkeit, s.388 vd., 586.

${ }^{22}$ Ayrıntılı bilgi için bkz. FRISTER, AT, §21 Rn.5-10.

Alman Ceza Hukukunda Tam Sarhoşluk Suçunun Dogmatik Temelleri
} 
Geisler, tam sarhoşluk suçunun tipik haksızlığ için sarhoş halde iken bir suç işlenmiş olmasının zorunluluğu karşısında, "hukuka aykırı bir fiil" (rechtswidrige Tat) ifadesinin yalnızca objektif cezalandırılabilme şartı olarak ele alınmasının kusur prensibini ihlal edeceğini ifade etmekte ve bu nedenle tam sarhoşluk suçunun somut tehlike suçu olarak anlaşılması ve buna göre değerlendirme yapılması gerektiğini savunmaktadır ${ }^{23}$.

Kaufmann'a göre de söz konusu hükmün mevcut şeklinin kusur prensibine aykırı olduğu rahatlıkla söylenebilir. Zira kusur prensibine göre verilecek ceza, failin kusurunun varlığı suretiyle hukuken haklı görülmekte ve cezanın miktarı failin kusuruna uygun olmalıdır. Buna rağmen Al.CK'nın 323a paragrafı bakımından bunu söyleyebilmek mümkün değildir. Kusur prensibinin varlığı için aranacak öncelikli şart haksızlık ve kusur arasında uyum olmasıdır. Kusur, fiilin haksızlığını kapsamalıdır, daha doğrusu fiilin bütün haksızlık içeriğine bağlı olmalıdır ${ }^{24}$. Tam sarhoş bir halde iken ceza tehdidi altına alınmış bir hareketin gerçekleştirilmesi, Kaufmann'a göre Al.CK'nın 323a paragrafının önceki halini karşılayan 330a paragrafının haksızlık unsuruna dahildir. Bundan dolayı da kusur prensibine göre failin kastının/taksirinin bu hususu da kapsaması gerekmektedir. Yazara göre burada "kusurdan băgımsız bir haksızlk unsuru" (schuldindifferente Unrechtsmerkmal) başka bir ifadeyle objektif cezalandırılabilme şartı bulunmaktadır. Objektif cezalandırılabilme şartlar ${ }^{25}$, fiilin haksızlığ 1 için önemli olmayan türde şartlardır ${ }^{26}$. Kaufmann, Al.CK'nın 330a paragrafının, kusur prensibi ile uyum içerisinde olmasının mümkün olmadığını da ifade etmektedir. Ancak yazara göre kusur prensibi ne şimdi ne de gelecekte hiçbir zaman kusursuz bir şekilde uygulanamayacaktır. Bu nedenledir ki Kaufmann, Al.CK'nın 330a paragrafını pek çok tartışmaları bünyesinde bulundurmasına rağmen varlığı zorunlu bir hüküm olarak gördüğünü sözlerine eklemektedir ${ }^{27}$.

Alman doktrininde başka yazarlar da söz konusu suç tipinin kusur prensibine uyumlu hale getirilebilmesi için, failin sarhoşken işlemiş olduğu fiilin öngörülebilir olmasını aramaktadırlar ${ }^{28}$. Yine bazı mahkeme kararlarında da failin cezai sorumluluğu yoluna gidilebilmesi için, failin sarhoş olduğu zaman cezalandırılabilir türde bir fiil gerçekleştirebileceğini en azından öngörmüş olmasının arandığı görülmektedir ${ }^{29}$.

Bu suç tipiyle ilgili tartışmalı konulardan bir diğeri ise söz konusu düzenlemenin in dubio pro reo ilkesine bir aykırılık oluşturup oluşturmadığıdır. Doktrinde ağırlıklı görüş tam sarhoşluk suçunun bu ilkeye aykırılık oluşturmadığ 1 yolundadır. Zira, suçun unsuru olan sarhoşluk fiili ile $\S$ 323a arasında çoktan aza giden "normatifsel-etik derecelendirme/basamak ilişkisi" (normativethisches Stufenverhältnis) bulunduğu ifade edilmektedir ${ }^{30}$. Türk Hukukunda pek s1k kullanılmayan ancak Alman Hukukunda siklıkla kullanılan bir terim olan "normatifsel-etik derecelendirme/basamak ilişkisi" nin varlığı ile kastedilmek istenen, bir suçun haksızlık içeriğinin bir başka suçun haksızlık içeriğini tamamen kapsamasının zorunlu olması, bir başka deyişle somut olayda uygulanma ihtimali bulunan iki norm arasında çoktan aza giden bir derecelendirme/basamak ilişsisinin bulunmasıdır. Bu ilişkinin varlığı halinde ya doğrudan doğruya ya da yorum yoluyla in dubio pro reo ilkesinin uygulanması suretiyle daha hafif cezayı gerektiren fiilden dolayı failin cezalandırılması söz konusu olacaktır. Bu kapsamda inceleme konusu tam sarhoşluk suçu açısından kişinin kusur yeteneğinin bulunmamasının suçun bir unsuru olduğu dikkate alındığında çoktan aza doğru giden bir derecelendirmeden bahsetmenin mümkün olmadığı anlaşılacaktır. Alman Hukukunda normatifsel-etik derecelendirme ilişkisi özellikle faillik-şeriklik ile azmettirme-yardım etme ilişkisi açısından dikkate alınmaktadır. Bununla birlikte bazı suç tipleri açısından da bu ilişkinin uygulandığı görülmektedir. Örneğin, yağma suçu ile hırsızlık suçu arasında benzer bir derecelendirme ilişkisi söz konusu olduğundan, yağmanın ayırt edici unsurlarının ispat edilememesi durumunda sanığın hırsızlık suçundan mahkûm edilmesine karar verilmesi gerekecektir. Konumuz açısından bakıldığında ise tam sarhoşluk suçu ile sarhoşken kişinin suç işlemesi (Rauschtat) arasında normatifsel-etik derecelendirme ilişkisinin olup olmadığ 1 tartışmalıdır. Bu kapsamda sarhoşken suç işlenmesinin tam sarhoşluk suçunun haksızlık içeriğini kapsayıp kapsamadığı ve

\footnotetext{
${ }^{23}$ GEISLER, Objektive Bedingungen der Strafbarkeit, s.388-411, 434-436, 586.

${ }^{24}$ KAUFMANN, Volltrunkenheit, s.426.

${ }^{25}$ Kaufmann'a göre objektif cezalandırılabilme şartlarının var olup olmadığı sadece terminolojik bir tartışma konusudur. Burada önemli olan kusurdan bağımsız haksızlık unsurlarının olduğudur. Bunların ne şekilde isimlendirildiği çok da önemli değildir. Bkz. KAUFMANN, Volltrunkenheit, s.430.

${ }^{26}$ KAUFMANN, Volltrunkenheit, s.429-430.

${ }^{27}$ KAUFMANN, Volltrunkenheit, s.433.

${ }^{28}$ KINDHÄUSER, BT I, §71 Rn.4; GÖSSEL/DÖLLING, BT 1, §59 Rn.1 ve dn.6'daki mahkeme kararlar1.

${ }^{29}$ BGHSt 10, 247, 250. Aksi yönde bkz. BGHSt 1, 124, 125 vd.; BGHSt 16, 124, 127.

${ }^{30}$ WESSELS/HETTINGER, BT 1, §23 Rn.1032.

Uğur ERSOY
} 
bununla birlikte failin yalnızca 323a paragrafından dolayı cezalandırılıp cezalandırılmayacağı da tartışmalı bir diğer konudur. Bununla birlikte tam sarhoşluk suçu için failin fiili işlediği sırada kusur yeteneğinin olmamasının suçun unsuru olarak kabul edilmesi gerçeği karşısında, kusur yeteneğinin olup olmadığı konusundaki şüphenin varlığının da failin lehine değerlendirme yapılması mümkün kılmayacağı ortadadır. Zira in dubio pro reo ilkesini olaya uygulayarak, failin fiili işlediği sırada kusur yeteneği olmadığı kabul edilse dahi değişen bir şey olmayacaktır. Benzer şekilde kast ve taksir arasında da in dubio pro reo ilkesinin uygulanması söz konusu olmaz. Bir başka deyişle bir suçun kasten mi yoksa taksirle mi işlendiği hususunda şüphenin bulunduğu durumlarda in dubio pro reo ilkesi gereği, sanığın otomatik olarak suçun taksirli şeklinden cezalandırılması mümkün değildir.

\section{HUKUKA AYKIRI FIIIL (RECHTSWIDRIGE TAT) KAVRAMI}

Alman Ceza Kanunu'nun 11/1 paragrafının 5 numaralı başlığında yer alan düzenlemeye göre hukuka aykirı fiil (rechtswidrige Tat) ile kastedilmek istenen tipe uygun ve hukuka aykırı fiildir. Bir başka deyişle tipe uygun ve hukuka aykırı fiilin varlığı halinde haksızlığın ve dolayısıyla suçun varlığından bahsedilir. Bu açıdan bakıldığında hukuka aykırı fiil ile kastedilmek istenenin suç/haksızlık olduğu söylenebilir. Tam sarhoşluk suçunda fail, hukuka aykırı fiil (rechtswidrige Tat) gerçekleştirmektedir; ancak sarhoş olmasından ötürü kusur yeteneğine sahip bulunmadığının tespit edilmesi veya kusur yeteneğine sahip olup olmadığının kesinlikle belli olamadığı için faili işlediği fiilden dolayı cezalandırma imkânı bulunmamaktadır ${ }^{31}$. Bu durumda fail, tam sarhoşluk suçundan dolayı cezalandırılmaktadır. İște bu husus, yani failin bu durumdayken hukuka aykırı bir fiil bir başka deyişle bir haksızlık/suç işlemesi, Alman doktrininde hâkim görüş tarafından yukarıda da ifade edildiği üzere objektif cezalandırılabilme şartı olarak kabul edilmektedir ${ }^{32}$. Alman doktrininde, kişinin kendi rızasıyla yani isteyerek sarhoş edici maddeler kullanması ve böylelikle kusur yeteneğini ortadan kaldırmak suretiyle Al.CK'nın 20. paragrafına göre ceza almaktan kurtulmasının adalet duygusunu çoğunlukla zedelediği de ifade edilmektedir. Bu nedenle kişinin kendini sarhoş hale sokması hukuka aykırı bir davranış olarak görülmektedir. Bununla birlikte, herhangi zararlı bir sonuca yol açmasa bile, her bir tam sarhoşluğu cezaya layık bir haksızlık olarak görüp cezalandırmak, kabul edilemez bir durum olarak değerlendirilmektedir. Bundan dolayı, failin böyle bir durumdayken hukuka aykırı bir fiil işlemesi objektif cezalandırılabilme şartı olarak yorumlanmaktadır ${ }^{33}$. Alman İmparatorluk Mahkemesi ve Alman Federal Yüksek Mahkemesi de söz konusu şartı objektif cezalandırılabilme şartı olarak değerlendirmektedir ${ }^{34}$.

Buna karşılık öğretide özellikle Bemmann tarafından savunulan görüşe göre gerek hâkim doktrin gerek yargı kararlarıyla kabul edilmiş olan bu durum kabul edilemez; çünkü yazara göre objektif cezalandırılabilme şartı diye bir şey aslında yoktur ${ }^{35}$. Bemmann, tam sarhoşluk bakımından aranan şartı objektif cezalandırılabilme şartı olarak değil suçun bir unsuru olarak nitelendirmekte ve diğer suç unsurlarında olduğu gibi burada da failin sorumlu tutulabilmesinin, failin kast veya

\footnotetext{
31 Alman doktrininde, kişinin kendi rızasıyla yani isteyerek sarhoş edici maddeler kullanması ve böylelikle kusur yeteneğini ortadan kaldırmak suretiyle Al.CK'nın 20. paragrafına göre ceza almaktan kurtulmasının adalet duygusunu çoğunlukla zedelediği ifade edilmektedir. Bu nedenle kişinin kendi kendini sarhoş hale getirmesi hukuka aykırı bir davranış olarak görülmektedir. Bununla birlikte, herhangi zararlı bir sonuca yol açmasa bile, her bir tam sarhoşluğu cezaya layık bir haksızlık olarak görüp cezalandırmak, kabul edilemez bir durum olarak görülmektedir. Bundan dolayı, bu durumda hukuka aykırı bir fiil işlenmesi objektif cezalandırılabilme şartı olarak değerlendirilmektedir. Bkz. PUPPE, Ingeborg: "Neue Entwicklungen in der Dogmatik des Vollrauschtatbestandes", JURA 1982, s.281.

32 BGHSt 16, 124, 125; ROXIN, AT I, §23 Rn.2; WESSELS/HETTINGER, BT 1, §23 Rn.1035; SONNEN, BT, s.252; SCHMIDT/PRIEBE, BT I, §323a Rn.699; EISELE, BT I, §323a Rn.1223; DENCKER, Vollrausch, s.2162; HOHMANN/SANDER, BT II, §38 Rn.15; GÖSSEL/DÖLLING, BT 1, §59 Rn.1; KINDHÄUSER, BT I, §71 Rn.20; PUPPE, Vollrauschtatbestand, s.281 vd.; OTTO, Vollrauschtatbestand, s.483; RANFT, Vollrauschtatbestand, s.245; SATZGER, Helmut, "Die objektive Bedingung der Strafbarkeit", JURA 2006, s.109; FRISTER, Helmut: Schuldprinzip, Verbot der Verdachtsstrafe und Unschuldsvermutung als materielle Grundprinzipien des Strafrechts, Berlin 1988, s.59; KAUFMANN, Arthur: Das Schuldprinzip, 2. Auflage, Heidelberg 1976, s.247; KINDHÄUSER, Urs: Strafgesetzbuch Lehr- und Praxiskommentar: 4.Auflage, 2010, Vor \$13 Rn.228; WEBER, Gunther: Das Delikt der folgenschweren Volltrunkenheit nach §330a StGB, 1970, s.19-20; RENGIER, Rudolf: Strafrecht Besonderer Teil II - Delikte gegen die Person und die Allgemeinheit, 12. Auflage, München 2011, §41 Rn.13; VON HEINTSCHEL-HEINEGG, Bernd: Strafgesetzbuch Kommentar, München 2010, §323a Rn.9; OTTO, Harro: Grundkurs Strafrecht - Die einzelnen Delikte, 7. Auflage, Berlin 2005, §81 Rn.7; GEPPERT, Klaus: "Die Volltrunkenheit (§323a StGB)”, JURA 2009, s.41; CRAMER, Peter: Der Vollrauschtatbestand als abstraktes Gefährdungsdelikt, Tübingen 1962, s.112; WEBER, Helmuth von: "Die Bestrafung von Taten Volltrunkener", MDR 1952, s.642.

${ }^{33}$ Bkz. PUPPE, s.281.

${ }^{34}$ BEMMANN, Rauschtat, s.67.

${ }^{35}$ BEMMANN, Rauschtat, s.68; BEMMANN, Günter: Zur Frage der objektiven Bedingungen der Strafbarkeit, Göttingen 1957 , s.52 vd. 
taksirinin bunu kapsaması şartıyla söz konusu olabileceğini ifade etmektedir ${ }^{36}$.

Hâkim görüşe göre burada cezalandırılabilme bir objektif şarta bağlıdır; cezalandırma ancak bir yandan daima tipe uygun ve hukuka aykırı olarak gerçekleştirilen bir fiile, öte yandan failin kusurunun aranmadığı objektif bir şartın gerçekleşmesi koşuluyla söz konusu olabilmektedir ${ }^{37}$. Failin bu objektif şartın gerçekleşeceğini öngörüp öngörememesi veya hatta bu şartın gerçekleşmesini engelleyip engelleyememesi, failin davranışı ile şartın gerçekleşmesi arasında nedensellik bağ bulunup bulunmadığı sorusu gibi önemsiz görülmektedir ${ }^{38}$. Bu durumu eleştiren görüşler haklı olarak şu soruyu sormaktadırlar: Fail açısından bakıldığında, kendisinin cezalandırılmasının tamamen keyfiliğe ve tesadüflere bırakılmış olması ne derece doğrudur? ${ }^{39} \mathrm{Bu}$ nedenle daha önce de ifade edildiği üzere söz konusu hükmün kusur prensibine ve dolayısıyla da Federal Alman Anayasasına aykırı olduğu şeklinde görüşler de ileri sürülmektedir ${ }^{40}$.

\section{SONUÇ}

Alman Ceza Kanunu'nda düzenlenmiş olan tam sarhoşluk suçunun 765 ve 5237 sayılı Türk Ceza Kanunu'nda doğrudan bir karşıllığı bulunmamaktadır. Buna karşın 765 sayılı TCK'nın 571 ile 575. maddeleri arasında sarhoşluk fiilinin, kabahat nevinden bir suç olarak düzenlendiği görülmektedir. 5326 sayılı Kabahatler Kanunu'nun 35. maddesinde de sarhoşluk fiilinin kabahat olarak düzenlendiği dikkati çekmektedir. Bu açıdan bakıldığında Alman Ceza Kanunu'ndaki tam sarhoşluk suçu ile 5237 sayılı TCK'da doğrudan karşılaştırılabilecek bir suç tipi olmadığ1 söylenebilir.

Tam bu noktada Türk ve Alman Hukuklarındaki durumun karşılaştırılması için Jescheck'in yapmış olduğu açıklamalara da kısaca değinmekte yarar görmekteyiz. Yazara göre Türk Hukukunun sarhoşluk ile ilgili hükümleri, Alman Hukukuna oranla daha serttir. Türk Hukukunda iradi sarhoşluğun bütün türleri cezai sorumluluk açısından göz önünde tutulmazken, Alman Hukukunda sadece ALIC (actio libera in causa) bu şekilde düzenlenmiştir. Buna karşın, taksirle veya kasten yaratılan sarhoşluk hali, Alman Ceza Kanunu'nun 323a paragrafinda özel bir suç tipi olarak kaleme alınmıştır. Fail sarhoşken bir suç işlerse, kişinin sarhoş haldeyken suç işlemesi objektif cezalandırılabilme şartı olarak kabul edilir ve kusurun bunu kapsaması gerekmez. Jescheck Alman yarg1 kararlarına bakıldığında, failin kendi kusuru ile sarhoş olduğu durumlarda gerçekleştirdiği fiiller bakımından ceza verilirken adeta objektif sorumluluk sınırına gelindiği şeklindeki tespiti de inceleme konusu açısından büyük öneme haizdir ${ }^{41}$. Alman Hukuku açısından 323a paragrafinın bu kadar tartışılmasının temelinde, Alman Ceza Kanunu'nda TCK m.34'tekine benzer bir düzenlemeye yer verilmemiş olması gerçeği yatmaktadır. Bu bağlamda Alman ceza hukuku doktrininde bir görüş ALIC'in varlı̆ğ halinde bile normatif bir düzenleme olmamasından ötürü failin cezalandırılmasını mümkün görmemektedir; zira kural gayet basittir: Kusur yoksa, ceza da yoktur! (Keine Strafe ohne Schuld!). Bu görüştekilere göre böyle bir durumda failin cezai sorumluluğu yalnızca $\S 323$ a çerçevesinde söz konusu olabilecektir. Buna karşın Alman doktrininde egemen olan görüş, § 323a'nın, ALIC'in uygulanma imkânı bulunmadığı durumlarda devreye girebilecek bir norm olduğu şeklindedir; bir başka deyişle ALIC'in uygulanma imkânı varsa § 323a'nın tatbiki söz konusu olmayacaktır.

Çalışma sırasında ele alınan konulardan bir diğeri olan ve söz konusu suç tipini kusur prensibiyle uyumlu hale getirmek için Alman doktrininde ileri sürülen, failin cezalandırılması yoluna gidilebilmesi için failin sarhoşken işlediği fiilin en azından "öngörülebilir" olmasını arayan görüş kanaatimizce isabetli görülmemektedir. Zira "öngörülebilirlik" kavramı taksirle ilgili bir terimdir. Kastta, öngörülmüş olanın aynı zamanda ya "istenmiş" olması ya da en azından "kabullenilmiş" olması gerekmektedir. Alman kanun koyucusu tarafından taksir formülasyonu çerçevesinde ele almadığ 1 tam sarhoşluk suçunda, fail hakkında cezaya hükmedebilmek için "öngörülebilirliğin” aranması, her ne kadar suç tipini kusur prensibiyle uyumlu hale getirme amacına matuf olsa bile kanun koyucunun yerine geçme sonucunu doğurabileceğinden sıkıntılı bir

\footnotetext{
${ }^{36}$ BEMMANN, Rauschtat, s.74.

${ }^{37}$ SATZGER, JURA, s.110; JAKOBS, Günther: Strafrecht Allgemeiner Teil - Die Grundlagen und die Zurechnungslehre Lehrbuch, 2. Auflage, Berlin-New York 1991, §10 Rn.2. Jakobs, burada aranan sarhoş durumdayken hukuka aykırı bir fiil gerçekleştirilmesini, "haksızlığın geçmişe etkili erteleyici şartı" olarak nitelendirmektedir. Zira yazara göre sarhoşluk, bu durumdayken herhangi bir fiil gerçekleştirilmediği sürece hukuka uygun görülebilir; ama şayet fail bu durumdayken hukuka aykırı bir fiil gerçekleștirir ise o takdirde geçmișe etkili olarak cezalandırılacaktır.

${ }^{38}$ SATZGER, JURA, s.110. Alman doktrinindeki hâkim görüş de bu yöndedir. Bkz. WEBER, Volltrunkenheit, s.19.

${ }^{39}$ SATZGER, JURA, s.110.

${ }^{40}$ FRISTER, Schuldprinzip, s.59,68.

${ }^{41}$ JESCHECK Hans-Heinrich: Alman Ceza Hukukuna Giriş - Kusur İlkesi - Ceza Hukukunun Sınırları (Çev.: Feridun Yenisey), İstanbul 2007, s.156 ve dn.13. 
durumdur.

Acaba TCK'da tam sarhoşluk suçuna benzer bir suç tipini düzenlemek gerekmekte midir? Kanaatimizce TCK'nın 34. maddesindeki düzenlemenin ve dolayısıyla ALIC ilkesinin hukukumuz açısından -tartışmalı olmakla birlikte- yürürlükte olması gerçeği karşısında, Al.CK § 323a'dakine benzer bir hükmün TCK'ya alınmasına gerek bulunmamaktadır. Kaldı ki çalışma kapsamında açıklanmaya çalışıldığı üzere Alman ceza hukuku doktrininde söz konusu suç tipinin kusur prensibine aykırı olduğu yolundaki ciddi ve haklı eleştiriler dikkate alındığında ceza hukuku dogmatiği açısından böylesine sorunlu ve kusur prensibiyle uyumsuz bir suç tipinin TCK'ya alınmasının faydadan çok zarar getireceğini ayrıca bu düzenlemenin TCK'nın 34. maddesi ile uyumsuzluk yaratacağını düşünmekteyiz.

\section{KAYNAKÇA}

BEMMANN, Günter: "Welche Bedeutung hat das Erfordernis der Rauschtat im § 330a StGB?”, GA 1961.

BEMMANN, Günter: Zur Frage der objektiven Bedingungen der Strafbarkeit, Göttingen 1957.

CRAMER, Peter: Der Vollrauschtatbestand als abstraktes Gefährdungsdelikt, Tübingen 1962.

DENCKER, Friedrich: "Vollrausch und der sichere Bereich des § 21 StGB", NJW 1980.

EISELE, Jörg: Strafrecht - Besonderer Teil I, Straftaten gegen die Person und die Allgemeinheit, 2. Auflage, Stuttgart 2012.

FRISTER, Helmut: Schuldprinzip, Verbot der Verdachtsstrafe und Unschuldsvermutung als materielle Grundprinzipien des Strafrechts, Berlin 1988.

GEISLER, Claudius: “Objektive Strafbarkeitsbedingungen und 'Abzugsthese' - Methodologische Vorüberlegungen zur Vereinbarkeit objektiver Strafbarkeitsbedingungen mit dem Schuldprinzip", GA 2000.

GEISLER, Claudius: Zur Vereinbarkeit objektiver Bedingungen der Strafbarkeit mit dem Schuldprinzip - Zugleich ein Beitrag zum Freiheitsbegriff des modernen Schuldstrafrechts, Berlin 1998.

GEPPERT, Klaus: "Die Volltrunkenheit (§ 323a StGB)”, JURA 2009.

GÖSSEL, Karl Heinz/DÖLLING, Dieter: Strafrecht Besonderer Teil 1 - Straftaten gegen Persönlichkeits- und Gemeinschaftswerte, 2. Auflage, Heidelberg 2004.

HARDWIG, Werner: "Studien zum Vollrauschtatbestand" in: Festschrift für Eberhard Schmidt zum 70. Geburtstag, 1971.

HOHMANN, Olaf/SANDER, Günther M.: Strafrecht Besonderer Teil II - Delikte gegen die Person und die Allgemeinheit, 2. Auflage, München 2011.

JAKOBS, Günther: Strafrecht Allgemeiner Teil - Die Grundlagen und die Zurechnungslehre Lehrbuch, 2. Auflage, Berlin-New York 1991.

JESCHECK Hans-Heinrich: Alman Ceza Hukukuna Giriş - Kusur İlkesi - Ceza Hukukunun Sınırları (Çev.: Feridun Yenisey), İstanbul 2007.

KAUFMANN, Arthur: "Unrecht und Schuld beim Delikt der Volltrunkenheit”, JZ 1963.

KAUFMANN, Arthur: Das Schuldprinzip, 2. Auflage, Heidelberg 1976.

KERNER, Hans-Jürgen: Kriminologie Lexikon, 4. Auflage, Heidelberg 1994.

KINDHÄUSER, Urs: Strafgesetzbuch Lehr- und Praxiskommentar, 4. Auflage, 2010.

KINDHÄUSER, Urs: Strafrecht Besonderer Teil I - Straftaten gegen Persönlichkeitsrechte, Staat und Gesellschaft, 5. Auflage, Baden-Baden 2012.

LANGE, Richard: "Die Behandlung der Volltrunkenheit in der Strafrechtsreform”, JR 1957.

OTTO, Harro: "Der Vollrauschtatbestand (§ 323a StGB)”, JURA 1986.

OTTO, Harro: Grundkurs Strafrecht - Die einzelnen Delikte, 7. Auflage, Berlin 2005.

PUPPE, Ingeborg: "Neue Entwicklungen in der Dogmatik des Vollrauschtatbestandes”, JURA 1982.

RANFT, Otfried: “Grundprobleme des Vollrauschtatbestandes (§ 323a StGB)”, JA 1983.

REINEKE, Alexander: Der wegen Trunkenheit vermindert schuldfähige Täter, Hamburg 2010.

RENGIER, Rudolf: Strafrecht Besonderer Teil II - Delikte gegen die Person und die Allgemeinheit, 12. Auflage, München 2011.

ROXIN, Claus: Strafrecht Allgemeiner Teil, Band I, Grundlagen - Der Aufbau der Verbrechenslehre, 4.Auflage, München 2006.

SATZGER, Helmut: “Die objektive Bedingung der Strafbarkeit”, JURA 2006.

SCHMIDT, Rolf/PRIEBE, Klaus: Strafrecht - Besonderer Teil I, Straftaten gegen die Person und die Allgemeinheit, 10. Auflage, 2011.

SONNEN, Bernd-Rüdeger: Strafrecht Besonderer Teil, Heidelberg 2005.

VON HEINTSCHEL-HEINEGG, Bernd: Strafgesetzbuch Kommentar, München 2010.

WEBER, Gunther: Das Delikt der folgenschweren Volltrunkenheit nach §330a StGB, 1970.

WEBER, Hellmuth von: "Die strafrechtliche Verantwortlichkeit für die Rauschtat", in: Studien zur Strafrechtswissenschaft - Festschrift für Ulrich Stock zum 70. Geburtstag am 8. Mai 1966, Würzburg 1966.

WEBER, Helmuth von: “Die Bestrafung von Taten Volltrunkener”, MDR 1952.

WESSELS, Johannes/HETTINGER, Michael: Strafrecht Besonderer Teil 1 - Straftaten gegen Persönlichkeits- und Gemeinschaftswerte, 35. Auflage, Heidelberg 2011. 